\title{
Cultural Assemblage as Genius Loci: Character Analysis of Medan City Center District
}

\author{
Hari Hajaruddin Siregar ${ }^{1, *}$, Petrus Natalivan ${ }^{2}$, Agus Suharjono Ekomadyo $^{3}$ \\ ${ }^{1}$ Student of Magister Urban Design, School of Architecture, Planning and Policy Development, Institute Technology Bandung, \\ Indonesia \\ ${ }^{2}$ Assistant Professor in Urban Planning and Design Research Group, School of Architecture, Planning and Policy Development, \\ Institute Technology Bandung, Indonesia \\ ${ }^{3}$ Associate Professor in Architectural Design Research Group, School of Architecture, Planning and Policy Development, Institute \\ Technology Bandung, Indonesia
}

\begin{abstract}
The city of Medan was formed from a rapidly growing plantation industry in the 1800s. The area that was originally only a village called Medan Putri with a population of about 200 people slowly changed since the Dutch investors saw the prospect of tobacco plantations in this region (Sinar, 2006). The amount of manpower needed to manage the plantation resulted in the investors bringing labor from Java, China and also Tamil. Moving the central government of the Deli Sultanate to Medan in 1891 increasingly crowded Medan at that time. The Arabs, Mining, Mandailing, and Aceh began to arrive for trading purposes as Medan began to grow and become more crowded. The study focused on locating the genius loci of Medan City through tracing the historical meaning by adapting the method undertaken by Norberg Schultz in tracing the spirit of the place and genius loci. The result of the analysis shows the role of culture and economic background that plays a major role in the formation of the character of Medan City center. The city is formed from the history of the plantation industry as well as the diverse cultures that share the same attachment and goals in the economic field.
\end{abstract}

Keywords: culture, character, genius loci, spirit of place, urban Reading in Architecture: Explorative Textual

\section{Introduction}

As the third largest metropolitan city, after Jakarta and Surabaya, with 2,210 million of population and and have about $265.10 \mathrm{~km} 2$ land area (Pemko Medan, 2013), Medan is now home for working people from various ethnicities and different cultures backgrounds. This cultural diversity will indirectly bring a unique social interaction between communities in accordance with culture and the culture itself and essentially require public space to perform such activities (Tanjung, 2015).

The city of Medan was formed from a rapidly growing tobacco plantation industry in the 1800 s. The village area originally named Medan Putri slowly changed when Dutch investor Nienhuys saw the prospect of tobacco planta-tions in this region (Sinar, 2006). Medan Putri originally inhabited by the Malay community began to flourish and attract many people coming from various ethnic groups. The development of a plantation industry that requires a lot of manpower encourages investors to bring in more planter and laborers from outside Medan. Manpower imported comes from Java, Tamils and Chinese (Sinar, 2006). The transfer of the royal administrative center of the Deli Kingdom from Labuhan to Medan further increased the crowds of Medan at that time. This transfer of royal government center invites other ethnic groups from outside to come and open their business in this area. Other ethnicities that come next are ethnic Mandailing, Minang, Aceh and also Arabs.

Ethnic diversity in Medan City has been going on since the past and is now has been taken as consideration to find the character of the city of Medan itself. The research undertaken aims to reveal how this ethnic diversity will influence the formation of urban character now. The re-search will be conducted by conducting historical searches on related literature and doing direct observation in the field. This research will later reveal facts in the field related to the role of culture towards the formation of the character of a city.

\section{Methods}

This study was conducted using space-based approach based on historical analysis in the research area. Data collection techniques are done by doing some historical record that occurred in the area of research and then seen in sequence phenomena that occur in the region. Combined with direct observation techniques will be

Corresponding author: hari.hajaruddin.siregar@gmail.com 
seen the phenomenon that occurred in the current region refers to the history of the area that has been collected. This approach is considered very suitable because we can trace the phenomenon of culture and history that occurred in the area of research in order to obtain the character of the region or sense of place sought.

Each place or region has a local spirit or intelligence that makes the place come alive, this spirit is often referred to as a unique has an-other name "guardian spirit" (Genius Loci) that distinguishes one place from another (Norberg-Schulz, 1980). This research is explorative, where the data to be collected is obtained through direct observation techniques in the study area and collect information through interviews to the competent parties in the field such as cultural and history experts who under-stand the history of the region and cultural his-tory in the city of Medan.

This approach is chosen because it can explain the phenomenon that occurs in the research area so that it can find a sense of place or character of the region. In revealing the character or spirit of place of the design area, the same stages are done by Norberg-Schultz in identifying the locus genius in several case studies in his book. Diagrammatically, the concept used is in Figure 1.
Medan Puteri was still a population of about 200 people only in 1923 (Sinar, 2006). Medan Putri Village is located close to the Deli River, one of the main rivers at that time which can still be used as a means of transportation (based on informant interview 2). In addition to the area of Medan Putri, other activity centers are in Labuhan in the north and Deli Tua in the south (Sinar, 2006).

In 1869 a Dutch investor came, Nienhuys, and started a plantation industry in Medan. Nienhuys set up his office and residence, Deli Mij, at the Deli River intersection because it was a strategic position for hauling the estate. At that time the road infrastructure is not good and still use the river as the most effective means of transportation. For transportation needs at that time then made several docks or harbor barge at Deli River intersection (Sinar, 2006). The first development ofplantation industry made by Nienhuys at that time, he brought some workers from outside Medan which is ethnic Javanese, Chinese and Tamil. Some of the existing buildings at that time were Hotel De Boer (Hotel Dharma Deli) as well as some Dutch resident buildings near the current House of Representatives (Sinar, 2006).

Since the tobacco plantation industry entered a

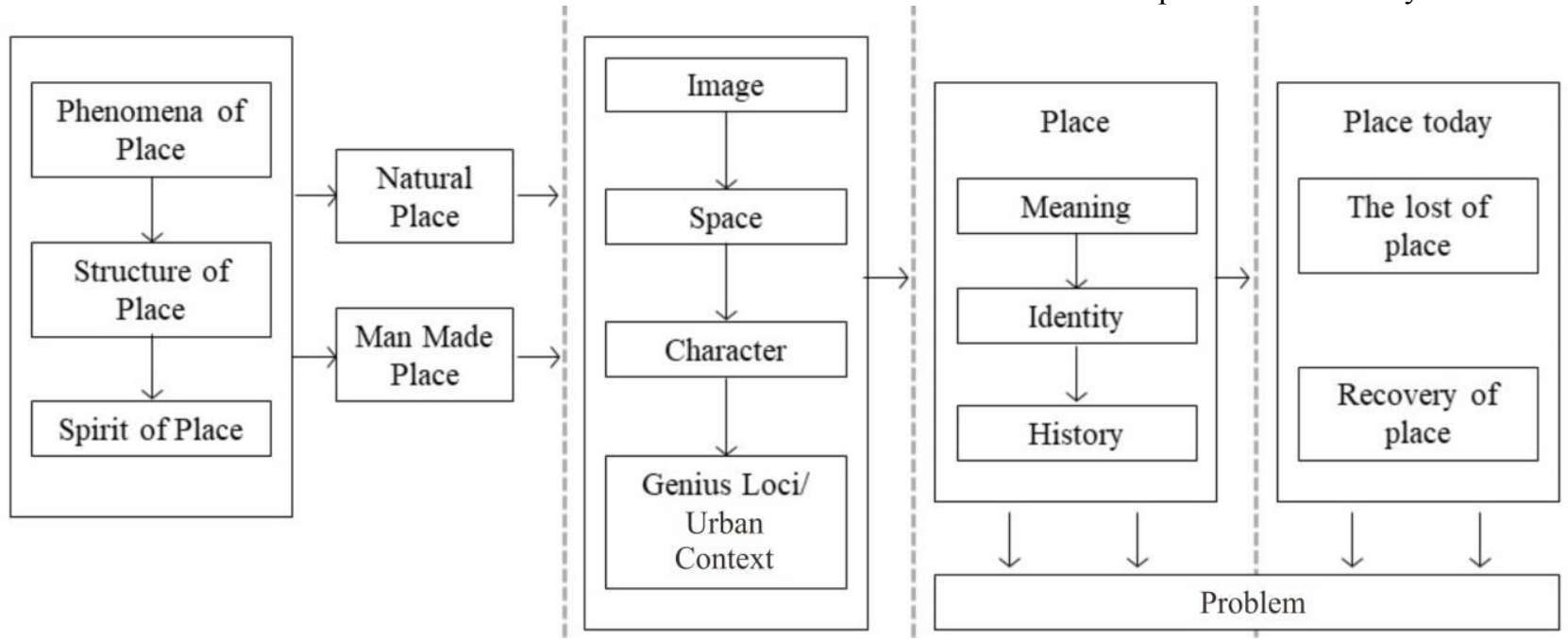

Fig. 1. The search process of finding Genius Loci. Source: Norberg-Schultz, 1991.

The plot in figure 1 is a technique or the way Norberg-Schultz invented Genius Loci in his book Genius Loci: Towards a Phenomenology of Architecture. In this study, genius loci sought only limited to the understanding of the context of the region approaching the character of the study area. This is done to shorten the study period but still get the character of the area you want to find.

\section{Results and Discussion}

\section{City Phenomenon}

Traced from its history, the city of Medan is formed from a small village called Medan Putri. Based on a report written by Jhon Anderson, a British delegate, glorious period in 1881, and the Deli Sultanate got great benefit from it, a plan to relocate the central government of Deli Sultanate from Labuhan to Medan had been started. Under the leadership of Sultan Deli IX, Maimoon Palace was built in 1888 and completed 3 years later. Since the

establishment of Maimoon Palace followed by the construction of the Grand Mosque of $\mathrm{Al}$ Ma-Shun, Taman Sri Deli and also the Castle of Puri, the area around it be-came an exclusive and respected area at that time because it is the central area of Deli Malay Sultanate in Medan (Sinar, 2006). Regions, such as courtyards and Sri Deli Pool is a property belonging to the sultanate that not just anyone can enter it. Even the people traveling across the palace would descend from his bike and lead him to a certain distance due to his respect for the deli sultanate at the time. At this time more and more migrants who open businesses and live in the city of Medan among others Mandailing people, Minang, Aceh and Arab. 
Since the social revolution that took place in East Sumatra in 1946, driven by the communists, there have been attempts to abolish the Malay kingdom system that exist in East Sumatra. During the year, many of the Malay sultanate assets were burned and destroyed (Kahin, 1952). After this revolution, the area began to open to the public and began crowded visited by the public because of the influence of the Sultanate of Deli at that time has begun to decrease.
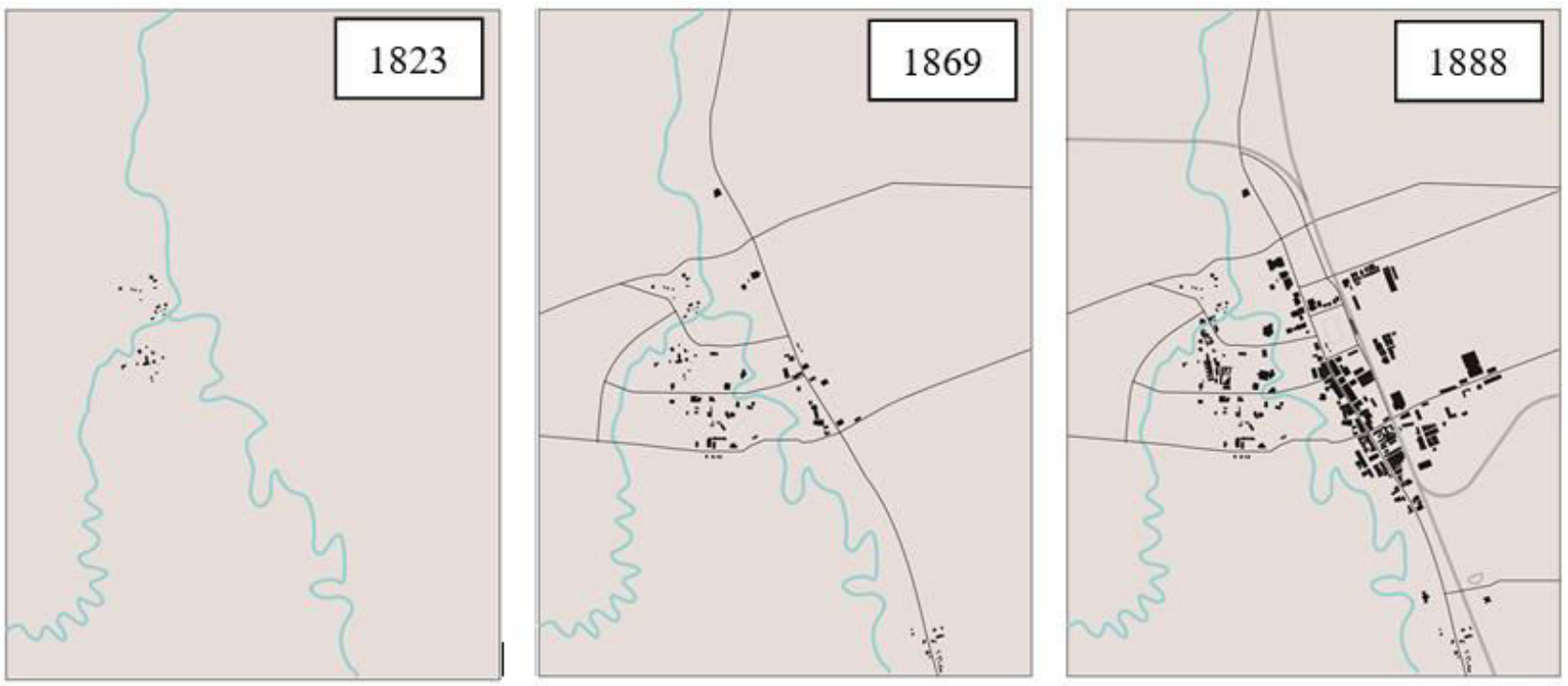

Fig. 2. Morphology of Medan City Center.

\section{City Structure}

Based on the morphology of the area in Figures 2 it can be seen that the area has evolved since the removal of the plantation industry office which was originally in Labuhan to Medan as well as the transfer of the Residency Center of East Sumatra from Bengkalis to Medan. Medan Putri initially only small village on the banks of the Deli River developed into a plantation area and commencement of construction of infrastructure and buildings sup-porting the plantation industry near the area. In the period 1879 - 1888 infrastructure development took place from the construction of roads, railways, sanitation networks, to tele-communications networks (Sinar, 2006).

Through the morphological picture, we can also see that there are two things that led to the development of the structure of Medan City area. The north of the developing region was driven by the need for the tobacco plantation industry and in the south of the developing region as it was driven by the displacement of the Deli Sul-tan Palace from Labuhan to Medan in 1891 after the completion of the construction of the palace which began in 1888 (Sinar, 2006).

The appointment of Medan as Gemeente in 1909 made the city divide in two areas of power, each of which was administered under the Sultanate of Deli and also the Dutch Residency. It aims to facilitate the regulation of the region as well as the laws prevailing in the region at that time. The people of Europe, ethnic Chinese, and tamils are obedient and governed under the leadership of the presidency. While the local population such as ethnic Malay, mandailing, Java, and Minang obedient and subject to the rules and orders of the sultanate.

\section{Image of The City}

The image of the region is shaped by cultural and historical background that has existed since ancient times. The entry of Dutch investors resulted in the development of plantation industry so that emerging areas that are man-aged and inhabited by people who manage the plantation. In the center of Medan (which be-came the current Merdeka Square) the image of the area was formed by colonial architectural buildings as it was the center of the gathering of offices of the plantation industry as well as the seat of the Dutch residency government (figure 4). Moving to the south (the corridors of Kesawan and surrounding areas) the image of the area is shaped by the typical two-storey shophouse buildings that are managed and inhabited by ethnic Chinese who are granted business and residence permits by residency at the time (figure 4). The farther south (the palace and the surrounding area) the image of the region is influenced by Malay culture and seen in its influence on the important buildings sur-rounding it (figure 5).

The diversity of existing cultures strongly affects the image of the region formed. The existence of this diversity led to the image of different areas in every corner of Medan. Some of the cultural spreading that occurred in Medan City can be seen in figure 3.

The image of the city was shaped by the historical and cultural background that existed from the past to the present. Where this image gets influence from the culture of Europe, Asia and Archipelago. Medan as one of the largest cities in Indonesia has cultural diversity. Uniquely from the existing cultures there is no one 
culture that is dominant in terms of social life or culture. Medan became a melting point, a blend of cultures that until now exist and transformed into a new culture that is different from the culture of origin.

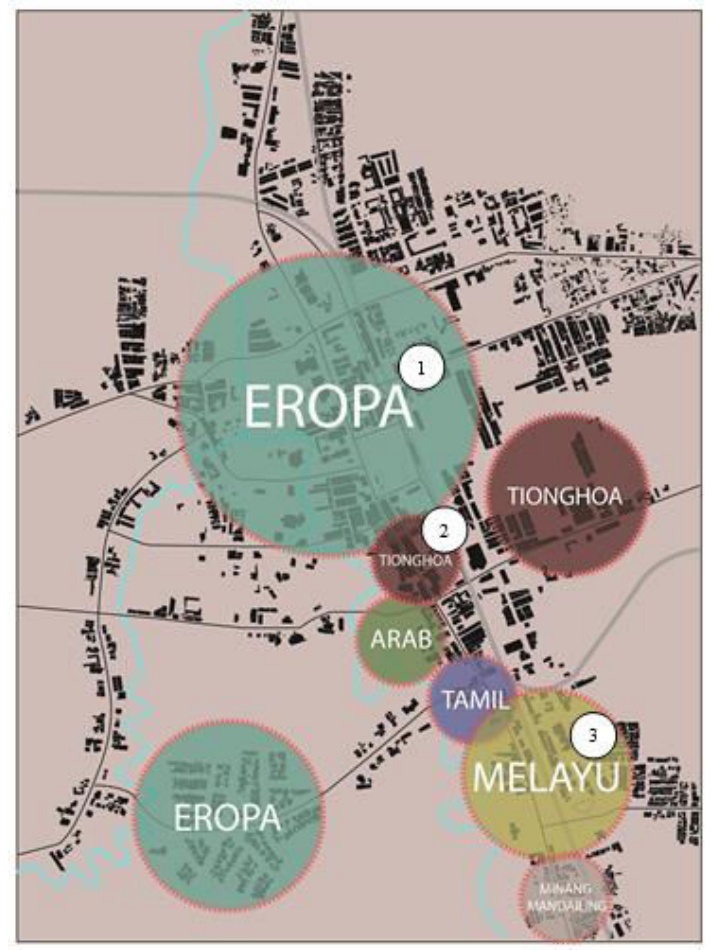

Fig. 3. Distribution of locations and settlements of various ethnic groups in Medan.

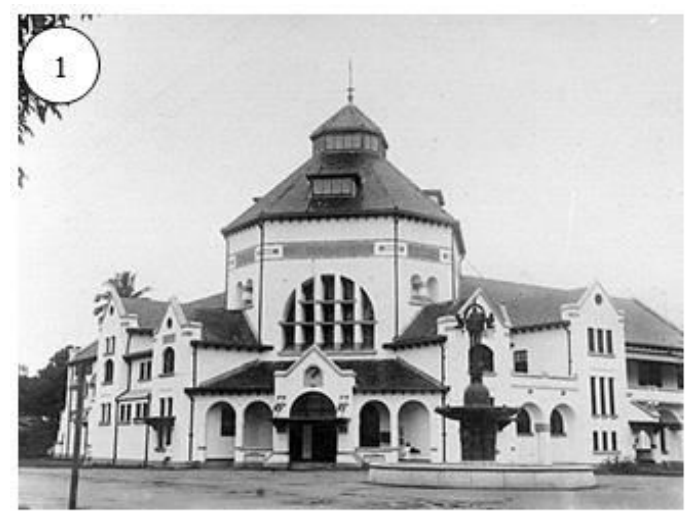

Fig. 4. Colonial-style buildings around Merdeka Square. Source: https://pussisunimed.files.wordpress.com accessed 23 Mei 2017.

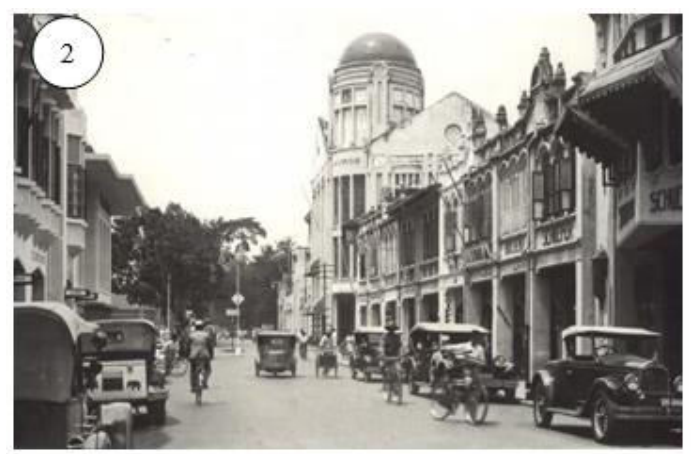

Fig. 5. Old Kesawan area.
Source: https://szlovely.files.wordpress.com accessed $23 \mathrm{Mei}$ 2017.

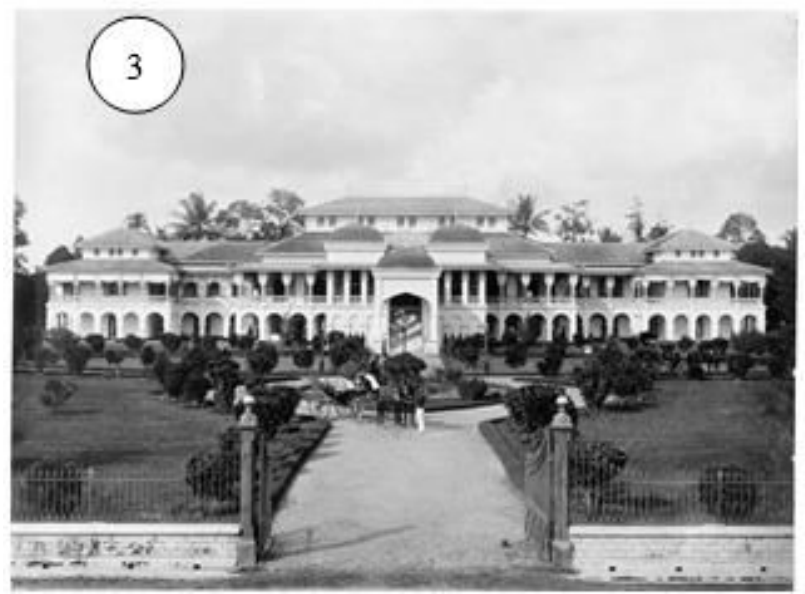

Fig. 6. Maimoon Palace and Puri Castle.

Source: https://www.wego.co.id accessed 23 Mei 2017.

\section{Space}

Space here is interpreted as an architectural container arising from the social interaction that occurred in it. This space can be both physical and non-physical in architectural terms (Ekomadyo, Zhara, \& Najmi, 2012). The spaces created in the city of Medan are formed and caused by the activity of the resonator in the area. these spaces are unique and interesting to discuss, because the historical and cultural backgrounds that contribute to them are very diverse. In the city of Medan there is some space formed on the need for a place of inter-action between European societies such as Medan Club (figure 7). This place was founded in 1880 by the Societteite de Witte, a gathering of Dutch people. For more complex interactions, occurs in the spaces formed by the market. There are several markets that have different historical backgrounds in accordance with the cultural mix that plays a role in its formation. Medan Central Market (figure 8) is the biggest market and main market in Medan City. Founded in 1933 during the reign of the Dutch East Indies. This market is shaped by the space requirements of the growing economic demands of the plantation. Here there is an interaction between various ethnic cultures in the city of Medan at that time.

Next is Kesawan area, space formed due to the interaction between ethnic Chinese and also the people of europe. Aside from being a residential area of ethnic Chinese, in this region there are also some important buildings that became the headquarters of government and also the plantation industry in the past. There is also a Hindu market and the area around the palace which has spaces formed due to the interaction between certain ethnic groups. 


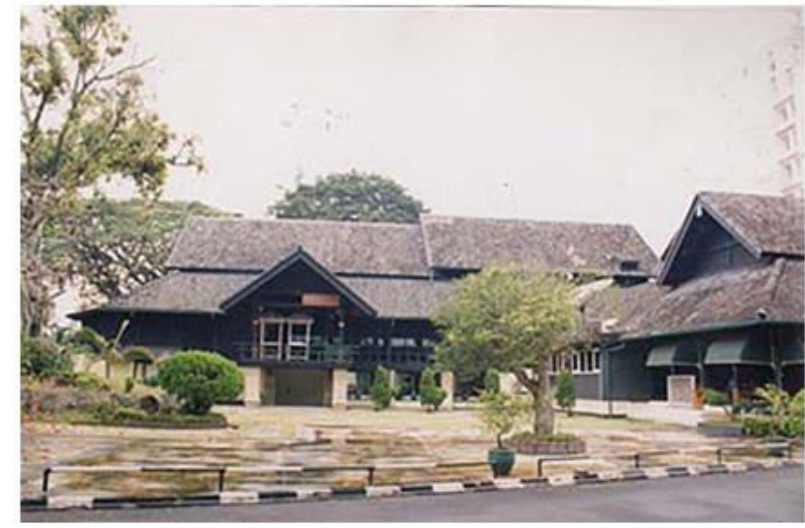

Fig. 7. Current Condition of Medan Club at Jalan Kartini. Source: http://medan.m-heritage.org ac-cessed 24 Mei 2017.

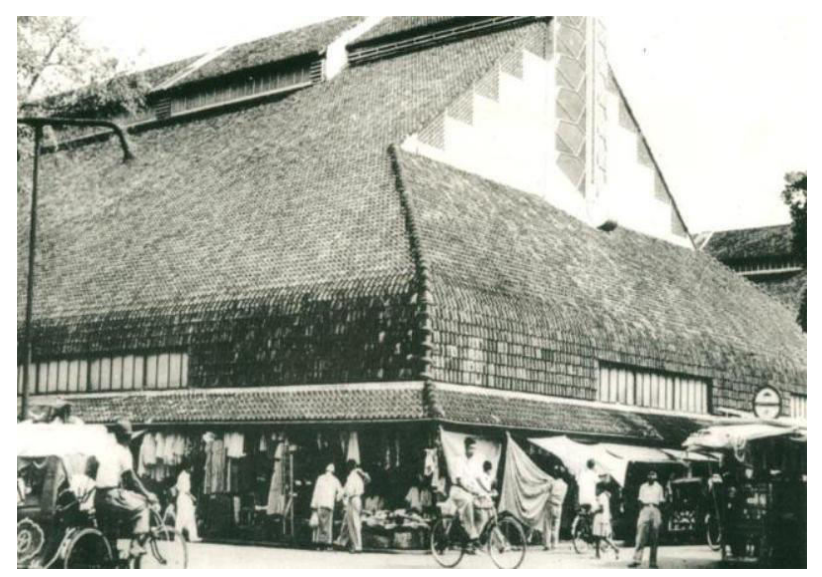

Fig. 8. Old Medan Central Market.

Source: https://deliheritageclub.files.wordpress.com accsessed 24 Mei 2017.

\section{Character}

Medan City has a character that has been formed by a strong history in the field of plantation industry and has the uniqueness of various ethnic cultures that participate in contributing to the face of the city today. Indirectly, the role of this ethnic diversity has an equal position without any dominance of a particular ethnicity. In its history Medan has been known as a metropolis area because it has become a center of trade and plantation that has a population of 14,000 (in 1905) to 76,000 (1930) from different ethnic backgrounds, not just entries from the archipelago but Europe, Asia and Arabic. So in other words the city of Medan is currently known as a city with a cultural form that has undergone mixing so that no one ethnic that has dominance

Cultural differences that contained in the city of Medan indirectly provide a new face and character to the city. The combinations of these different cultures and ethnic groups give a new form of architecture that is different from its original form. These new forms, until now, be-come new characters and faces owned by the city of Medan itself, a city that has a diversity of cultures whose manifestations can be seen from its architectural character.

\section{Genius Loci}

From the phenomenon of the area that occurred can be concluded that the city of Medan is formed by the activity of a very advanced plantation in ancient times. This plantation activity raises the interest of the world community and local people to come and open their business in this area. From the explanation it can be said that the genius loci Medan City is the cultural diversity formed by the history of economic activity that occurred in the region.

Characters in the context of Medan can be either implicit or explicit. Both of these are often interpreted as the spirit of place or genius loci (Jiven and Larkam, 2003). Today, the implicit evidence can be social concepts applied by society in different ways and dependent on their respective cultural concepts. While the concept of exploit itself looks firmly from the various forms of architecture owned by Medan City and still exist until today. Both of these also provide an overview that the city of Medan is a city with the concept of a character that is formed from different cultural and social assemblage.

\section{Conclusions}

In his book, Norberg-Schultz, uses three key-words to summarize the results of his explora-tion of the "place" he studies. These three key-words are meaning, identity and historicity. The meaning of "place" in the city of Medan is formed due to a mixture of cultures that are based on the need for the same economic ac-tivity. With the combination of culture that oc-curred then the city of Medan has a different cultural background that can revive and move the city's economy until now.

Different cultural backgrounds create spaces for activities that have unique characteristics. This cultural diversity will indirectly bring about social interaction between communities in ac-cordance with culture and essentially require public space to perform such activities (Tan-jung, 2015). Cultural differences that exist one of them can be seen from the shape and manifestation of architecture that until now still exist in the city of Medan. Where these buildings become a form of strong identity that can be used as a reflection of cultural diversity in this area physically.

The existence of the historic buildings in Medan city is a testament to the history of the strong development city in the past. Starting from the heyday of the plantation industry until the reign of Sultanate of Melayu Deli can be seen from the historical buildings that still exist today.

The city of Medan as one of the big cities in Indonesia, has uniqueness and distinctive char-acteristics of course different from other cities in Indonesia. Characteristics that characterize the city of Medan is the diversity of culture it has. This cultural diversity is formed due to the history of economic development driven by the plantation industry that existed since ancient times. This economic movement also continues to this day. 


\section{Acknowledgements}

Thank God I pray to Allah SWT and all parties who have helped in the preparation of this re-search paper, from the beginning of data col-lection until the analysis process. To Mr. PetrusNatalivan and Mr. Agus Ekomadyo as thesis supervisors who have a lot contributed to the content of this research. Thanks to all those who have assisted in the data collection process in Medan, for informants who have taken the time to provide information related to history and culture of Medan city, such as Mr. Khairul (BWS), Mr. Edi Sumarno (Lecturer of History of FIB USU), Mrs. Rozanna (Chairman of the Faculty ofMalay Culture), Mr. Anto, Mr. Ridwan as the guards of the Great Mosque and Maimun Palace, Mrs. Isnen (Lecturer of Archi-tecture USU), Mr. Umar, Mr. Muzahar and Mr. Usman as experts in the field of antopology and history. As well as some local people who helped provide information related to this re-search area. Thanks to relatives and friends who have given their moral support and en-couragement until the research is done on time.

Ligula dolor vel ipsum posuere consequat grav-ida, mauris at, in suscipit magna libero enim mauris a. Sed ut imperdiet ridiculus.

\section{References}

Ekomadyo, A. S., Zhara, A., \& Najmi, I. (2012). Public Market as Urban Social Nodes: An Architectural Phenomenology Approach. Arte-Polis 4 International Conference - Creative Connectivity and the Making of Place.

Jiven,G \& Larkam, P.J. (2003). Sense of Place, Authenticity and Character: A Com-mentary. Journal of Urban Design, Vol. 8, No. 1, 67-81

Kahin, G. M. (1952). Nationalism and Revolution in Indonesia. Cornell University Press.

Leushuis, E. (2014). Panduan Jelajah Kota-Kota Pusaka di Indonesia. Yogyakarta: Penerbit Ombak.

Norberg-Schulz, C. (1980). Genius Loci: Towards A Phenomenology of Architecture. London: Academy Edition.

Sinar, T. L. (2006). Bangun dan Runtuhnya Kerajaan Melayu di Sumatera Timur. Medan: Yayasan Kesultanan Serdang.

Tanjung, F. (2015, September 30). Kompasiana. Retrieved from Kompasiana Rubrik: http://www.kompasiana.com/ftanjung/harapan-dantantangan-ruang-publik-kotamedan_560bdcbb0e977340081c61d7 